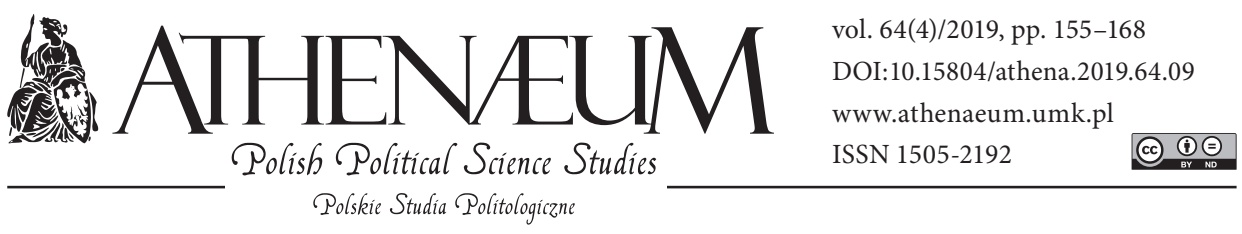

\title{
MEDIA POLITICAL BIAS: IN SEARCH OF CONCEPTUALIZATION
}

\author{
MEDIALNA STRONNICZOŚĆ POLITYCZNA: \\ W POSZUKIWANIU KONCEPTUALIZACJI
}

Rafał Klepka*

\begin{abstract}
The manner in which the media presents its recipients with political content has a strong impact on knowledge, attitudes, opinions and electoral behavior. The content of the media cannot be a full reflection of political reality, but the way in which the reality presents it may be closer or more distant from the idea of objectivity and neutrality. The category describing the scale of deviation from the idea of a balanced presentation of content is the media political bias. The aim of this article is to present this concept and determine the specific features of media political bias, its main determinants, elements of the media which make us deal with biased content, and the relationship between the concept of media political bias and other selected theoretical concepts regarding media.
\end{abstract}

Keywords: media; political bias; media content; objectivism; framing
Sposób, w jaki media prezentują swoim odbiorcom treści o charakterze politycznym, ma silny wpływ na wiedzę, postawy, opinie oraz zachowania wyborcze. Zawartość mediów nie może stanowić pełnego odzwierciedlenia rzeczywistości politycznej, jednak sposób, w jaki rzeczywistość tę prezentuje, może być bliższy lub dalszy od idei obiektywizmu i neutralności. Kategorią opisującą skalę odchylenia od idei zbalansowanej prezentacji treści jest medialna stronniczość polityczna. Celem niniejszego artykułu jest przybliżenie tej koncepcji oraz określenie specyficznych cech medialnej stronniczości politycznej, jej głównych uwarunkowań, elementów przekazu medialnego, które sprawiają, że mamy do czynienia $\mathrm{z}$ treścią o charakterze stronniczym, a także związku między koncepcją medialnej stronniczości politycznej a innymi wybranymi koncepcjami teoretycznymi dotyczącymi mediów.

Słowa kluczowe: media; stronniczość polityczna; zawartość mediów; obiektywizm; framing

* Pedagogical University of Cracow, named after the Commission of National Education, Faculty of Political Science. 


\section{INTRODUCTION}

Contemporary political reality is more and more connected with the world of media (Klepka, 2018b, pp.9-10). It is extremely difficult, especially in democratic states, to find cases in which citizens who take part in elections and referendums shape their knowledge, beliefs, assessments and, consequently, political decisions in a different way than through the media. The existing relationship between political processes and the media makes it necessary to study interrelations between them as important for understanding contemporary political phenomena. At the same time, researchers dealing with political processes, as well as scientists conducting media analyzes, journalists, media recipients and even politicians, very often emphasize that the media is unreliable, manipulative, false, present some of the truth and remain unobjective. Expectations of objectivity formulated for the media appear as often as reflections proving that objectivism is impossible to achieve, because media messages, even for technical reasons, are not able to fully reflect the political reality. The presence of a kind of paradox based on the formulation of expectations, despite the awareness that they cannot be realized, is an important, though not the only reason why the issue of media political bias appears as a valuable and cognitively rewarding research problem. Nevertheless, questions about the possibility of precise, scientific operationalization of the concept that would go beyond the colloquial, intuitive understanding of the essence of media bias remain relevant.

Polish researchers, both politics and the media, have repeatedly addressed the issue of bias in the media on the occasion of analysis of the political communication strategy (Kolczyński, 2007), the functioning of the Polish media system (Dobek-Ostrowska, 2011) and selected media concepts (Zawalska, 2013). One can also find studies on the content of the media, which used the category of political bias in more or less distinct way (Kolczyński, 2017; Radek, 2013). Research on this subject in the US and Western Europe is much more often carried out, being the subject of lively debate which takes place among scientists as well as politicians, employees of media institutions, journalists and ordinary media recipients (Street, 2001; Curran, 2011; McQuail, 1992; Ruschmann, 2006). Publications being the result of this research are of a theoretical, followed by a methodological and finally empirical nature, thus they build conceptualization and conceptual grid, define research methods and tools, and analyze content of a specific medium, or comparably several media, to capture existing patterns 
(Groseclose \& Milyo, 2005b; Haselmayer, Wagner, \& Meyer, 2017; Ho et al., 2011; Jak, Oort, \& Dolan, 2014; Mayer, 2005).

The aim of this article is to present the basic conceptualizations and ways of defining the specific features of the media political bias, its main conditions and elements of the media message, which make us deal with biased content. The findings presented in the article refer to traditional media, in particular, television. Regardless of the growing role played by new media, according to most studies, television is the main source of information on politics (Klepka, 2018a, pp. 15-18). In addition, due to the framework of the study, the presented concepts relate to the media in democratic countries. It should be emphasized, however, that also in this group of countries there are many differences that allow for the separation of model media systems, taking into account the complexity of relations between the media and politics (Hallin \& Mancini, 2004, pp. 21-45).

\section{BIAS AS THE OPPOSITE OF OBJECTIVITY AND BALANCE}

There is a relatively large ease in an intuitive understanding of the concept of media bias. We deal with it in a situation where one's rations, views, political parties, ideologies, value systems, religions, nations, professions are favored, presented in a good light, while others are criticized, discriminated, presented in a negative way (Dobek-Ostrowska, 2011,p. 70). Therefore, the bias may concern not only politics, but also religion, attitudes, nationalities or advertised products (Guo \& Lai, 2014).

In the case of media political bias, it should be noted that, as Tim Groseclose and Jeffrey Milyo point out, we deal with it mainly in information programs and media dealing with political issues, unlike other forms of media bias that may also occur in entertainment programs, TV series or commercials. Political bias understood in this way, according to American researchers, means the inclination of the media message in such a way that it becomes left-wing or right-wing and consequently favors one of the political parties (Groseclose \& Milyo, 2005b, p. 306). Political bias, therefore, allows to talk about the division into liberal and conservative media or pro- and anti-, with the given prefix being a given political value or an important theme from the current political agenda. In the USA, the most popular theoretical concepts referring to media bias often formulate the assumption that mainstream media are predominantly liberal or rarely that they 
mainly promote conservative values (Groseclose \& Milyo, 2005a, p. 1192; Lee, 2005; Mayer, 2005).

Ewa Nowak-Teter emphasizes the differences between slant, which means the inclination, distortion and one-sidedness of the relationship in which some elements are emphasized, and ignores others, from bias, defined as consistent and long-lasting one-sidedness of the message. The researcher points out, however, that in the Polish literature on the subject, the persistence of a particular power or political reason has often been described as political bias (Nowak-Teter, 2017, p. 105).

Bias in the subject literature is often defined as the opposite of objectivity (Cushion \& Thomas, 2017, p. 2). It should be pointed out here that the difficulty in assessing whether the message fulfills this criterion is far-reaching. The choice of events or words for presentation, the shortness of media forms, or cultural diversity are factors that make it difficult to assess whether the material presents objectively political reality. There is no doubt that the comprehensive selection of sources and their confrontation with each other favor a multilateral view of the given issue. Researchers sometimes also have to refuse to treat as certain information from government documents or state offices, which should also be subject to journalistic verification (Puglisi \& Snyder, 2016, p. 649). The constructivist stand, in turn, assumes - in a far-reaching simplification - that reality is not directly accessible to the individual, while learning about the world is an individual construction of meanings. Observation of the world is therefore its construction and depends on the observer. Constructivism recommends looking from the outside on the problem of media objectivity, because according to this position, the mass media is not about reflecting reality, but only about its construction, and therefore it cannot be indicated to what extent it is objective, because reality is not available for the observer (Fleischer, 2005, p. 10, 2007, p. 29; Michalczyk, 2010, p. 107).

Most often, defining media bias is accompanied by an indication that the media should be balanced. This postulate can be understood in many ways. On the one hand, as a balance, on the other as equality in access and the manner of presenting specific parties, candidates or political reasons. Only in some cases, balance and equality can be interpreted in the same way. In majority political systems with two political parties, such a solution seems obvious (D’Alessio \& Allen, 2000). Balance consists in a relatively equal time and manner of presenting each of the two political parties. There is a possibility of using a similar way of understanding the balance in two-block systems, when there are many parties, 
but the division axes also allow for a relatively equal presentation of each block's reasons (Hopmann, Van Aelst, \& Legnante, 2012, p. 244).

Determining what is the balance in multi-party systems is a much more difficult task. It certainly does not mean the same as equality. By presenting during the electoral campaign the conventions of the two main parties competing in the elections and devoting $70 \%$ of their broadcasting time to them, the information program may follow the principle of balance, because these conventions were the most important political events of the day, and smaller groups were not active that day. Such an arrangement of an information program in a multiparty electoral system does not mean equal treatment of the parties, because the smaller political groups participating in the elections did not have the chance to present their program to the extent comparable with the two main parties. In the opposite situation, if each of the ten political parties taking part in the election were devoted in the information program to $10 \%$ of the airtime, it would turn out that full equality does not mean balance. In the case of two parties, an important political event took place, but the others would have to be presented only in order to fill in the airtime in the right proportions. In the case of small parties just aspiring to be on the political scene, the creation of journalistic material of significance and size analogous to that devoted to large political parties could be an extremely difficult task or even impossible for an experienced team of journalists. This state of affairs means that the political relevance of a party determines its rank in media political programs. In other words, the balance means that more time and attention is devoted to larger parties already with their representatives, incumbents and well-known politicians, while the pretenders, representatives of small groups and political novices are condemned to less attention of the media (Bennett, 1990; Hopmann et al., 2012, p. 245).

The difficulty of clearly defining media political bias results in some researchers treating it as imperfections resulting from the lack of journalistic norms or their failure to comply with media. They point to the lack of journalistic ethics or precision in journalistic codes. Often bias is also treated as a departure from journalistic professionalism. In normative conceptions there are often presumptions that bias is a consequence of the fact that media employees remain in too close relations and dependencies with political actors and the demand that political journalism should be only informative, so it should be crucial to separate facts from values and assessments (Asp, 2014, p. 261).

As the most coherent and still valid concept one should recognize the findings made in the $1970^{\text {s }}$ by researchers from the Glasgow Media Group, who 
indicated that "Contrary to the claims, conventions, and culture of television journalism, the news is not a neutral product. For television news is a cultural artifact; it is a sequence of socially manufactured messages, which carry many of the culturally dominant assumptions of our society. From the accents of the newscasters to the vocabulary of camera angles; from who gets on and what questions they are asked, via selection of stories to presentation of bulletins, the news is a highly mediated product" (Glasgow University Media Group, 1976, p. 1). This position proves that the expectations of neutrality from media messages about politics are, in fact, exaggerated and impossible to implement.

For a better understanding of the media specificity of political bias, one should point to its gradual nature. Thus, every media message is situated in the area of the continuum between full objectivity and extreme bias (Louw, 2005, p. 78; Curran, 2002, p. 155; Klepka, 2017, p. 157). This assumption is illustrated by the diagram below.
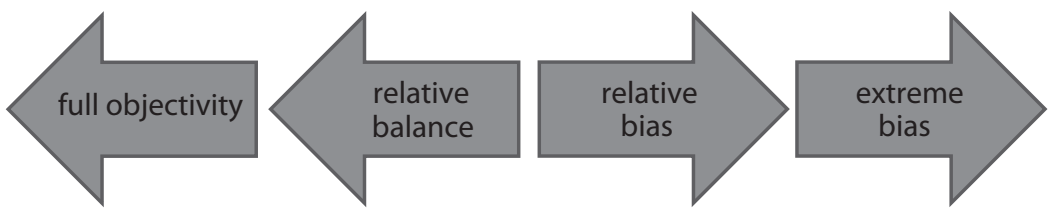

Scheme 1. Continuum between Objectivity and Political Bias in Media Coverage

Source: own study.

\section{TYPOLOGIES OF MEDIA POLITICAL BIAS}

Researchers of media political messages analyzing the issue of bias also try to organize existing concepts in various ways, creating typologies of the phenomenon itself and its basic dimensions. Two, often hard to distinguish, forms of media bias can be indicated. The first of them, which should be described as unintentional political bias, to a large extent remains independent of the creators of the media. It is a consequence of the fact that the media image of a phenomenon always remains a fragment and an abbreviation. Each journalist or editor, regardless of intentions, will select a different part of the speech, illustrate his statement with another politician, because of the limited duration of the material or the volume of the article will omit the selected fragment. This kind of bias can 
be regarded to a certain extent as a natural consequence of the media coverage of reality (Łódzki, 2017, p. 123).

The intended political bias should be treated differently. It involves presenting political phenomena in such a way as to favor the selected side of a political conflict, a political party or supporters of a particular solution while at the same time negatively evaluating the opposite party, or omitting information about its existence altogether (Toggle, 1998, p. 65). David N. Hopmann, Peter Van Aelst and Guido Legnante point to three basic dimensions of the intended political bias (Hopmann et al., 2012, p. 247). The first one refers to the visibility of political actors, who can be given more or less attention, thereby rewarding or eliminating their points of view. The sound of materials presented in the media plays a significant role. Using an innumerable range of resources, it is possible to evaluate a particular political actor in an unambiguously favorable or critical manner. The role of journalistic commentary, narrative, confrontation with the past or other political actor will play a huge role (Donsbach \& Patterson, 2004, p. 251). Finally, the third dimension concerns the selection of problems that will be addressed. Purposeful selection can lead to the elimination of selected points of view or over-representation of materials dedicated to a specific issue.

Dennis McQuail proposes a more complex typology of political bias, making the criteria of its division intentionality, as in the previous typology, but also adding a second criterion, that is, openness. On this basis, he distinguishes propaganda, ideological, unmistakable and involuntary bias (McQuail, 1992, p. 191). The specificity of this division is illustrated in the diagram below.

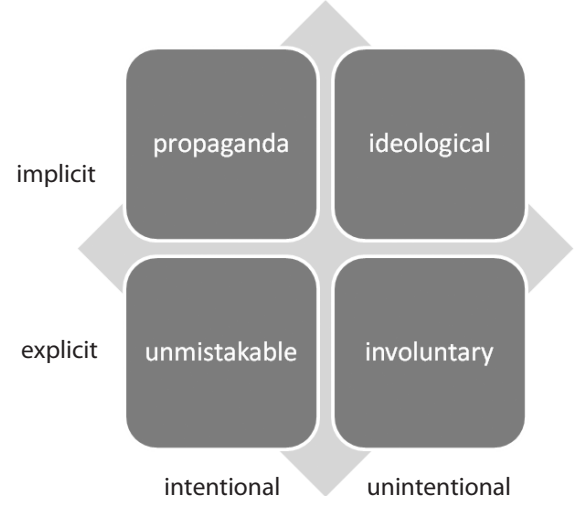

Scheme 2. Types of Political Bias

Source: own study based on McQuail, 1992, pp. 191-193. 
The implicit but intentional propaganda bias relies on such a media message formulation to smuggle in as many things as possible that would support a particular party, point of view, or worldview. The ideological bias, also hidden, but also unintentional, relies on the formulation of certain value judgments, which reveal itself only during careful reading of the newspaper or several analysis of media coverage, they are a consequence of what the editors treat as obvious and clear, and the adoption of such assumption has biased character. Intended and overt partiality is undoubtedly the explicit communication of the editorial line or views expressed by the journalist, and even encouragement to vote in the elections for a specific political party or candidate. Finally, involuntary bias, i.e., unintentional and explicit, is conditioned by restrictions on the duration of the broadcast or the volume of the newspaper and is associated with the necessary choices and abbreviations, which inevitably affect the accuracy of the media message.

\section{POLITICAL BIAS AND OTHER MEDIA CONCEPTS}

The concept of media political bias remains in various relationships and dependencies with other theories of media functioning (Baran \& Davis, 2011, p. 16; Michalczyk, 2015, p. 7). Most of them belong to the medium-range theory, and thus interdisciplinary scientific concepts referring to a selected aspect of the media phenomenon of political bias. The complexity and multidimensionality of bias itself is well illustrated by the diagram presenting elements of the process of production of media political messages and their reception by media consumers.

The diagram presents both factors that can influence media bias, as well as the most important stages of media coverage from the political events to the reception of the message that concerns them. Almost every stage of content creation can lead to action, which in turn will lead to the material being biased. The selection of events, topics, problems or politicians to which the media devotes their attention is the subject of research into the concept of gatekeeping and the theory of the value of information. Gatekeeping explains "the process by which countless occurrences and ideas are reduced to a few messages we are offered in our news media" (Shoemaker \& Vos, 2009, p. 75). Leading researchers conducting analyzes within this concept consider the selection processes on five different levels: individual, communication routine, organizational, social institutions, 


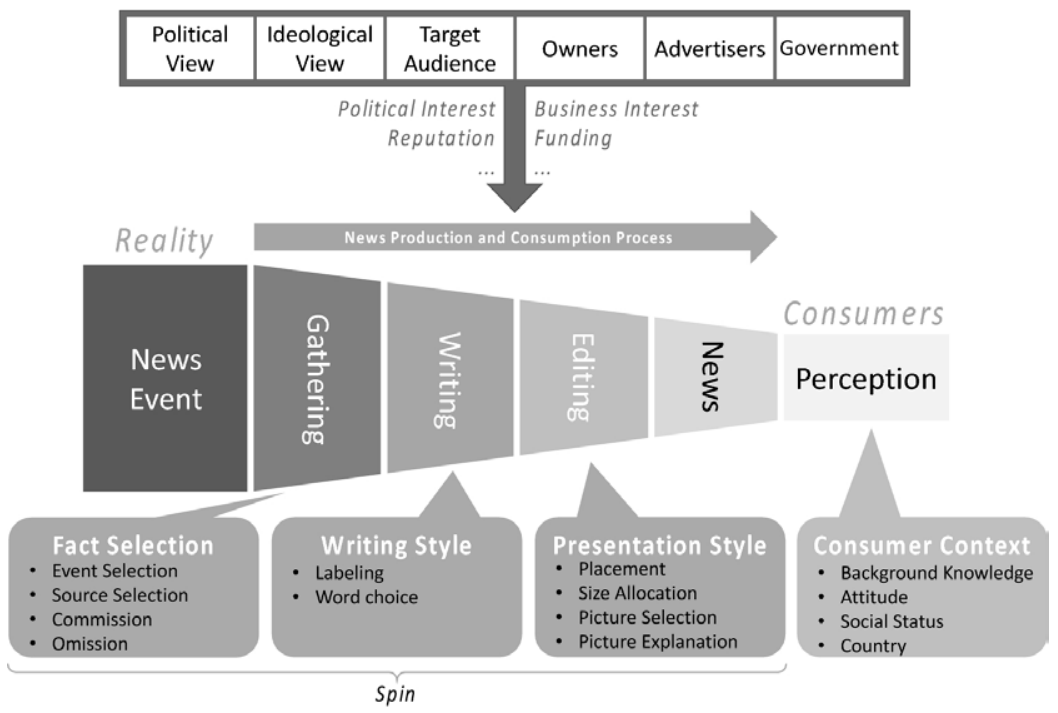

Scheme 3. Elements of the Process of Production and Reception of Political Media Messages That May Affect Their Bias

Source: F. Hamborg, K. Donnay, \& B. Gipp, Automated Identification of Media Bias in News Articles: An Interdisciplinary Literature Review. International Journal on Digital Libraries, 16.11.2018; S. Park, S. Kang, S. Chung, \& J. Song, NewsCube: Delivering Multiple Aspects of News to Mitigate Media Bias.

and social system. The choice of topics to be addressed for issue or publication depends on the characteristics of the person making the decision, its demographic profile, life experience, professed values, attitudes, professional experience, further from the routine of the media organization, unwritten rules, such as the priority of specific topics, resignation from others, limiting selected issues as uninteresting to recipients, or placing emphasis on messages from a specific range of issues. The next level involves decisions about the choice of subject with the economic interests of the media organization, its target market, competition, advertising market and knowledge about the expectations of recipients, as well as the place of media organization among other institutions, advertisers and their goals, government, interest groups and interconnected networks. The last level is connected with the most widely understood surroundings and its features, such as the state supervision system over the media, the political system, the economic system in a given country, the influence of culture or ideology. 
Research devoted to the mere selection of content allows to find numerous general trends that make media policy messages biased. The exemplification of Stuart N. Soroka's research can be indicated as the conclusion of the study of the existence of "negativity bias" consisting in much more frequent news in the media, such as irregularities, scandals, campaign mistakes or improperly spent funds, than messages that would carry positive content behind them (Soroka, 2016). Other studies show that in the course of election campaigns, the media pay more attention to incumbents and more often talk about them positively (Eraslan \& Ozerturk, 2017), and that the media are eager to write more and give their messages a positive tone when the message concerns a party supported by most recipients of a given medium (Haselmayer et al., 2017).

The process of selecting information should also be associated with the theory of information value, which proves the existence of a relationship between the characteristics of a specific political event and the probability of its presentation in the media. The concept assumes that particular attention is drawn to conflicts, negative events, recent events, scandalous ones, and referring to the audience's experiences (Allan, 2004, p. 57). Such patterns of selection of the presented topics undoubtedly affect the presence and constant repetition of information about selected problems, politics or parties and the omission of others.

A concept that indirectly also refers to media bias is the agenda setting (McCombs \& Reynolds, 2009). According to it, the media create in our minds a map of important and less important things, which is additionally perpetuated in the minds of people constantly using the media. The rank and importance of topics is determined by the frequency of their occurrence, the order of the information provided, which creates order in the minds of recipients, giving the importance of topics from the most important to the less important to the trivial ones. Messages that start major news releases, journal cover art or the problems of the most extensive articles in weekly magazines are considered more important than the information that was provided at the end of the site or about which only one column was written in a newspaper or magazine. Thus it creates an agenda of important matters for the recipients that in an automatic way positions the rank of topics, political parties or the politicians themselves.

The media theory which is extremely often associated with media political bias is framing. This concept refers to the framework in which a given topic or policy is presented in the media and how it is perceived by the recipients. Robert Entman emphasizes that framing is a ubiquitous process in politics and policy analysis. It consists of selecting several aspects of the perceived reality and com- 
bining them in a narrative promoting a particular interpretation. The framework can be selected from four functions: defining the problem, determining the cause, passing moral evaluations, and presenting remedies (Entman, 1993, 2010). The message concerning a politician or a party may adequately refer to positive traits, such as honesty, efficiency or economy, as well as to past events, when a party or politician lost, made a mistake, were involved in a specific political scandal. Including the appropriate scheme means that the recipients evaluate positively or negatively, give them specific opinions, connect with past events and the relevant fragment of knowledge, shape the assessment, attitude and point of view.

The concept that explains why the media in a systemic way present the reality in a non-objective manner remains the propaganda model of Edward Herman and Noam Chomsky. It was created in the $1980^{\mathrm{s}}$ in the USA and concerned non-state media, however, a significant part of the arrangements made at the time remained valid and could be related to the state media in Europe to a significant extent. According to the model, empirically tested many times, there are five filters that determine what messages will appear in the media: ownership of the medium, medium's funding sources, sourcing, flak, and anti-communism or "fear ideology" (Herman \& Chomsky, 1988, pp. 1-35). The propaganda model is still the starting point of many studies referring to political bias in the media.

\section{CONCLUSIONS}

Presented theoretical considerations do not pretend to a full analysis of concepts relating to media political bias. They can, however, be a starting point to determine the essence of the problem. Terminological findings should favor the creation of methodological proposals relating to how to study media political bias, using what methods, how to construct research tools. At the same time, it seems that studies of this kind cannot be limited only to qualitative research, but should also be quantitative. In this context, it is reasonable to ask the question about the possibility of measuring the media political bias. With the right tools and research methods, political scientists and media experts would be able to compare the direction and scope of political bias of various media and make comparisons between different media, as well as research in different periods of time. Properly constructed methodological proposals would allow conducting empirical research in several basic directions: determining the level and direction of political bias of selected types of media, specific television and radio stations, 
broadcasts or magazines. In addition, well-designed research would enable conducting media analysis of bias in particularly important periods, such as the time of electoral campaigns.

\section{ReFERENCES:}

Allan, S. (2004). News Culture. New York: Open University Press.

Asp, K. (2014). News Media Logic in a New Institutional Perspective. Journalism Studies, 15(3), 256-270. DOI: 10.1080/1461670X.2014.889456.

Baran, S.J., \& Davis, D.K. (2011). Mass Communication Theory: Foundations, Ferment, and Future. Boston: Wadsworth, Cengage Learning.

Bennett, W.L. (1990). Toward a Theory of Press-State Relations in the United States. Journal of Communication, 40(2), 103-127. DOI: 10.1111/j.1460-2466.1990. tb02265.x.

Curran, J. (2002). Media and Power. London, New York: Routledge.

Curran, J. (2011). Media and Democracy. London, New York: Routledge.

Cushion, S., \& Thomas, R. (2017). From Quantitative Precision to Qualitative Judgements: Professional Perspectives about the Impartiality of Television News During the 2015 UK General Election. Journalism, 20(3), 392-409. DOI: $10.1177 / 1464884916685909$.

D’Alessio, D., \& Allen, M. (2000). Media Bias in Presidential Elections: A Meta-Analysis. Journal of Communication, 50(4), 133-156. DOI: 10.1111/j.1460-2466.2000. tb02866.x.

Dobek-Ostrowska, B. (2011). Polski system medialny na rozdrożu: media w polityce, polityka w mediach. Wrocław: Wydawnictwo Uniwersytetu Wrocławskiego.

Donsbach, W., \& Patterson, T.E. (2004). Political News Journalists: Partisanship, Professionalism, and Political Roles in Five Countries. In: F. Esser, \& B. Pfetsch (eds.). Comparing Political Communication: Theories, Cases, and Challenges (pp. 251-270). Cambridge: Cambridge University Press.

Entman, R.M. (1993). Framing: Toward Clarification of a Fractured Paradigm. Journal of Communication, 43(4), 51-58. DOI: 10.1111/j.1460-2466.1993.tb01304.x.

Entman, R.M. (2010). Media Framing Biases and Political Power: Explaining Slant in News of Campaign 2008. Journalism, 11(4), 389-408. DOI: $10.1177 / 1464884910367587$.

Eraslan, H., \& Ozerturk, S. (2017). Information Gatekeeping and Media Bias. Presented at the Rochester, NY. Retrieved from: http://eaf.ku.edu.tr/sites/eaf.ku.edu.tr/files/ erf_wp_1808.pdf.

Fleischer, M. (2005). Media w perspektywie konstruktywizmu. $2 \mathrm{~K}$ - Kultura i Komunikacja, 1-2, 10-33.

Fleischer, M. (2007). Zarys ogólnej teorii komunikacji. In: G. Habrajska (ed.). Mechanizmy perswazji i manipulacji (pp. 29-72). Łask: Leksem. 
Glasgow University Media Group (1976). Bad News. London: Routledge \& Kegan Paul. Groseclose, T., \& Milyo, J. (2005a). A Measure of Media Bias. The Quarterly Journal of Economics, 120(4), 1191-1237.

Groseclose, T., \& Milyo, J. (2005b). A Social Science Perspective on Media Bias. Critical Review, 17(3-4), 305-314. DOI: 10.1080/08913810508443641.

Guo, W.C., \& Lai, F.C. (2014). Media Bias When Advertisers Have Bargaining Power. Journal of Media Economics, 27(3), 120-136. DOI: 10.1080/08997764.2014.931861.

Hallin, D.C., \& Mancini, P. (2004). Comparing Media Systems: Three Models of Media and Politics. New York: Cambridge University Press.

Haselmayer, M., Wagner, M., \& Meyer, T.M. (2017). Partisan Bias in Message Selection: Media Gatekeeping of Party Press Releases. Political Communication, 34(3), 367-384. DOI: 10.1080/10584609.2016.1265619.

Herman, E.S., \& Chomsky, N. (1988). Manufacturing Consent: The Political Economy of the Mass Media. New York: Pantheon Books.

Ho, S.S., Binder, A.R., Becker, A.B., Moy, P., Scheufele, D.A., Brossard, D., \& Gunther, A.C. (2011). The Role of Perceptions of Media Bias in General and Issue-Specific Political Participation. Mass Communication and Society, 14(3), 343-374. DOI: 10.1080/15205436.2010.491933.

Hopmann, D.N., Van Aelst, P., \& Legnante, G. (2012). Political Balance in the News: A Review of Concepts, Operationalizations and Key Findings. Journalism, 13(2), 240-257. DOI: $10.1177 / 1464884911427804$.

Jak, S., Oort, F.J., \& Dolan, C.V. (2014). Measurement Bias in Multilevel Data. Structural Equation Modeling: A Multidisciplinary Journal, 21(1), 31-39. DOI: 10.1080/10705511.2014.856694.

Klepka, R. (2017). Relacjonowanie polityki w „Wiadomościach” TVP1 po wyborach parlamentarnych w 2015 roku: obiektywne czy stronnicze? Political Preferences, 17, 155-172. DOI: 10.6084/m9.figshare.5723122.

Klepka, R. (2018a). Medialna walka o dobra zmianę: obraz wyborów parlamentarnych w 2015 roku w wybranych mediach. Kraków: Wydawnictwo Libron.

Klepka, R. (2018b). Obrazy polityki w mediach: podstawowe uwarunkowania. In: R. Klepka (ed.). Medialne obrazy świata. Wybrane problemy społeczno-polityczne w mediach (pp. 9-25). Kraków: Wydawnictwo Uniwersytetu Pedagogicznego. DOI: 10.24917/9788380841079.1.

Kolczyński, M. (2007). Strategie komunikowania politycznego. Katowice: Wydawnictwo Uniwersytetu Śląskiego.

Kolczyński, M. (2017). Stronniczość mediów w bipolarnym środowisku politycznym. Tygodnik „Polityka” w kampaniach wyborczych 2015 roku. Polityka i Społeczeństwo, 15(1), 33-47. DOI: 10.15584/polispol.2017.1.3.

Lee, T.T. (2005). The Liberal Media Myth Revisited: An Examination of Factors Influencing Perceptions of Media Bias. Journal of Broadcasting \& Electronic Media, 49(1), 43-64. DOI: 10.1207/s15506878jobem4901_4.

Louw, P.E. (2005). The Media and Political Process. London, Thousand Oaks, New Delhi: SAGE. 
Łódzki, B. (2017). Medialny obraz rzeczywistości. Studia Socialia Cracoviensia, 9(1), 121-136. DOI: $10.15633 /$ ssc.2305.

Mayer, W.G. (2005). What Conservative Media? The Unproven Case for Conservative Media Bias. Critical Review, 17(3-4), 315-338. DOI: 10.1080/08913810508443642.

McCombs, M., \& Reynolds, A. (2009). How the News Shapes Our Civic Agenda. In: J. Bryant \& M.B. Oliver (eds.). Media Effects: Advances in Theory and Research (pp. 1-16). New York, London: Routledge, Taylor \& Francis Group.

McQuail, D. (1992). Media Performance: Mass Communication and the Public Interest. London, Thousand Oaks, New Delhi: Sage Publications.

Michalczyk, S. (2010). Demokracja medialna. Teoretyczna analiza problemu. Torun: Wydawnictwo Adam Marszałek.

Michalczyk, S. (2015). Jednostka i społeczeństwo $w$ świecie mediów. Klasyczne i współczesne idee w teoriach średniego zasięgu. Katowice: Thesaurus Silesia.

Nowak-Teter, E. (2017). Rodzaje i przejawy tendencyjności w telewizyjnych programach informacyjnych w Polsce. e-Politikon, 21, 102-135.

Puglisi, R., \& Snyder, J.M. (2016). Empirical Studies of Media Bias. In: S.P. Anderson, J. Waldfogel, \& D. Strömberg (eds.). Handbook of Media Economics, Vol. $1 B$ (pp. 647-667). Amsterdam: Elsevier.

Radek, R. (2013). Obraz kampanii wyborczej do polskiego parlamentu w 2011 roku w prasie prawicowej. Przykład dziennika „Rzeczpospolita” i tygodnika „Uważam Rze”. In: M. Kolczyński (ed.). Współczesne kampanie wyborcze w Polsce: koncepcje, dylematy i praktyka komunikowania politycznego (pp. 72-92). Katowice: Uniwersytet Śląski, Wydawnicwo Gnome.

Ruschmann, P. (2006). Media Bias. Philadelphia: Chelsea House Publishers.

Shoemaker, P.J., \& Vos, T. (2009). Gatekeeping Theory. New York, London: Routledge, Taylor \& Francis Group.

Soroka, S.N. (2016). Gatekeeping and the Negativity Bias. Oxford Research Encyclopedia of Politics. DOI: 10.1093/acrefore/9780190228637.013.43.

Street, J. (2001). Mass Media, Politics and Democracy. Basingstoke: Palgrave Macmillan. Toggle, C.A. (1998). The Bias Toward Finding Bias in Television News. Communication Reports, 11(1), 65-72. DOI: 10.1080/08934219809367686.

Zawalska, M. (2013). Agenda mediów a ich stronniczość (telewizyjne serwisy informacyjne). Politeja. Pismo Wydziału Studiów Międzynarodowych i Politycznych Uniwersytetu Jagiellońskiego, 3, 555-568. DOI: 10.12797/Politeja.10.2013.25.32. 